\title{
Implementasi (EFA) Electronic File Archive Sederhana Berbasis Web
}

\author{
Suharmadi $^{1}$, Hendrik Setyo Utomo ${ }^{2)}$ \\ 1)2) Jurusan Teknik Informatika, Politeknik Negeri Tanah Laut \\ Jl. A. Yani Km.6 Pelaihari, Tanah laut \\ ${ }^{1)}$ suharmadi93@gmail.com \\ ${ }^{2}$ hendrik.tomo@politala.ac.id
}

\begin{abstract}
Abstrak
Proses pengarsipan Perusahaan PT. PLN (Persero) Unit Induk Pembangkitan dan Penyaluran Kalimantan UPDK Barito ULPLTA Ir. P.M. Noor menyimpan file didalam komputer masingmasing bagian. Komunikasi antar bagian dalam pengarsipan dilakukan dengan cara whatapps atau tools lainnya, sehingga adanya memerlukan ukuran file cukup besar. Tujuan penelitian yaitu rancang bangun electronic file archive (EFA)yang penerapannya berjalan pada jaringan server lokal yang terhubung ke seluruh bagian PLTA. EFA digunakan untuk melakukan pengarsipan secara elektronik dan dapat melakukan komunikasi antar pengguna. Pengujian yang dilakukan yaitu dengan menggunakan black box seluruh fungsional aplikasi berhasil dilakukan.
\end{abstract}

Kata kunci: electronic file archive, EFA, BlackBox, Web

\begin{abstract}
The process of filing the Company PT. PLN (Persero) Unit Induk Pembangkitan dan Penyaluran Kalimantan UPDK Barito ULPLTA Ir. P.M. Noor is storing files in the computers of each department. Communication between departments in archiving is done by means of whatapps or other tools, so that it requires a large file size. The purpose of the research is to design an electronic file archive (EFA) that applies to local networks that are connected to all departments. EFA is doing filing electronically and can communicate between users. Testing using the black box throughout the functional application is successful.
\end{abstract}

Keywords: electronic file archive, EFA, BlackBox, Web

\section{PENDAHULUAN}

Organisasi, perusahaan dan sejenisnya memiliki kegiatan untuk menggerakan operasional dengan tujuan yang akan dicapai. Kegiatan yang dilakukan menghasilkan berupa sebuah file word, excel atau jenis file lainnya. Hasil cetak file dilakukan pengarsipan dalam bentuk holder dokumen atau dalam bentuk soft file yang tersimpan dalam komputer.

Perusahaan PT. PLN (Persero) Unit Induk Pembangkitan dan Penyaluran Kalimantan UPDK Barito ULPLTA Ir. P. M. Noor merupakan Badan Usaha Milik Negara (BUMN). BUMN tersebut bergerak pada bidang ketenagalistrikan yang menghasilkan daya sebesar 3 x $10 \mathrm{Mega}$ Watt (MW). Kegiatan utama perusahaan BUMN tersebut yaitu beroperasi menghasilkan listrik untuk mengaliri wilayah Kalimantan Selatan dan Kalimantan Tengah. Perusahaan BUMN tersebut memiliki bagian atau divisi administrasi dalam menjalankan operasional perusahannya.

PLTA (BUMN) memiliki 3 bagian, yaitu Bagian Pemeliharaan, Bagian Operasi, dan Bagian Administrasi. Setiap bagian di PLTA memiliki arsip file yang disimpan ke dalam komputer masing-masing. Penyimpanan arsip file yang terpisah mengalami kendala yaitu tidak adanya backup data (file archive) pada masing-masing bagian, pencarian arsip file membutuhkan waktu, adanya terinfeksi virus komputer dan komunikasi antar bagian dalam memerlukan data atau arsip file membutuhkan waktu dengan tools seperti SMS (Short Message Service),WA (WhatsApp) atau jenis tools lainnya. 
Permasalahan yang telah diuraikan dapat diselesaikan dengan rancang bangun electronic file archive. Perangkat lunak nantinya diimplementasikan ke dalam sistem operasi linux sebagai server. Electronic file archive dibangun dengan database Mariadb sebagai tempat penyimpanan dan PHP sebagai memproses data berbasis web. Electronic file archive mampu mebantu menyelesaikan dalam backup data, membantu pencarian file seluruh bagian PLTA dengan hak akses ditetapkan, terhindar virus komputer dan membantu komunikasi antar bagian dalam memerlukan data (file archive).

\section{TINJAUAN PUSTAKA}

\subsection{Electronic (Digitalisasi) File Archive}

Hasil penelitian dalam Jurnal Teknologi Electrichsan, Universitas Ichsan Gorontalo (Asmara, 2014) tentang proses digitalisasi arsip dokumen penting program studi elektro dilakukan secara Local Interset ( $L I)$ menjadi file software dengan metode ekperimen dan alat pemindai digital sebagai media merubah menjadi soft file.

Presentasi Seminar Nasional PAP "Pengembangan Ilmu dan Profesi Adminsitrasi Perkantoran" (Kuswantoro, 2015), electronic arsip merupakan suatu sistem tempat penyimpanan diproses dengan komputer. Hasil penelitianya yaitu proses pembelajaran yang dilakukan SMK Jurusan Administrasi Pekantoran secara konvensional seperti pengarsipan dengan filling cabinet dilakukan perubahan menjadi $e$-arsip.

Artikel ilmiah dalam Jurnal Sisfotek global (Sidik, Sakuroh, \& Pratiwi, 2017), hasil yang dilakukan adalah konversi dari proses konvensional pada sistem filling bank BCA KCP MH Thamrin mulai dari penerimaan, pembuatan, pemyimpanan, pendokumentasian, dan verifikasi surat menjadi sistem informasi filling.

Menurut pendapat Setiawan (2017), era digitalisasi dapat melakukan perubahan besar terhadap dunia dan menciptakan berbagai macam teknologi baru, pada era digital juga memberikan manfaat dalam berbagai bidang yaitu politik, ekonomi, sosial budaya, pertahanan atau keamanan serta teknologi informasi yang memiliki tantangan dalam setiap pemanfaatannya.

\subsection{Basis Data}

Menurut Rosa dan Shalahuddin (2013) sistem basis data merupakan sistem terkomputerisasi dengan tujuan memelihara data yang telah diolah atau menjadi sebuah informasi dan memberikan ketersedian informasi pada saat dibutuhkan.

Sistem manajemen basis data merupakan suatu sistem aplikasi digunakan untuk menyimpan, mengelola dan menampilkan data (Rosa \& Shalahuddin, 2013). Sistem tersebut disebut juga dengan sistem manajemen basis data memiliki persayaratan minimal yaitu :
a. Menyediakan fasilitas dalam mengelola akses data
b. Mampu melakukan integritas data
c. Mampu melakukan akses data yang dilakukan secara bersamaan
d. Mampu melakukan backup data

\subsection{Unified Modeling Language (UML)}

UML merupakan bahasa yang banyak digunakan dalam industri untuk menetukan persyaratan, membuat analisis dan desain, serta menggambarkan arsitektur berorientasikan objek pemrograman (Rosa \& Shalahuddin, 2013). UML terdiri dari 3 jenis diagram :

a. Structure diagram terdiri dari diagram kelas, diagram objek, diagram komponen, diagram struktur komposit, diagram package dan diagram penyebaran.

b. Behavior diagram terdiri dari diagram usecase, diagram aktivitas dan diagram state machine

c. Interaction diagram terdiri dari diagram sekuen, diagram komunikasi, timing diagram, dan interaction overview diagram. 


\subsection{Pengujian Black Box}

Pengujian Black Box adalah menemukan kesalahan sebanyak-banyaknya dalam kategori: fungsi-fungsi yang tidak benar atau hilang, kesalahan interface, kesalahan dalam struktur data atau kases basis data eksternal, kesalahan kinerja dan inisialiasi dan kesalahan terminasi (Pratiwi, 2014).

\section{METODE PENELITIAN}

\subsection{Kerangka Penelitian}

Kerangka penelitian aplikasi EFA (Electronic File Archive) pada PT. PT. PLN (Persero) Unit Induk Pembangkitan dan Penyaluran Kalimantan UPDK Barito ULPLTA Ir. P.M. Noor sebagai berikut:

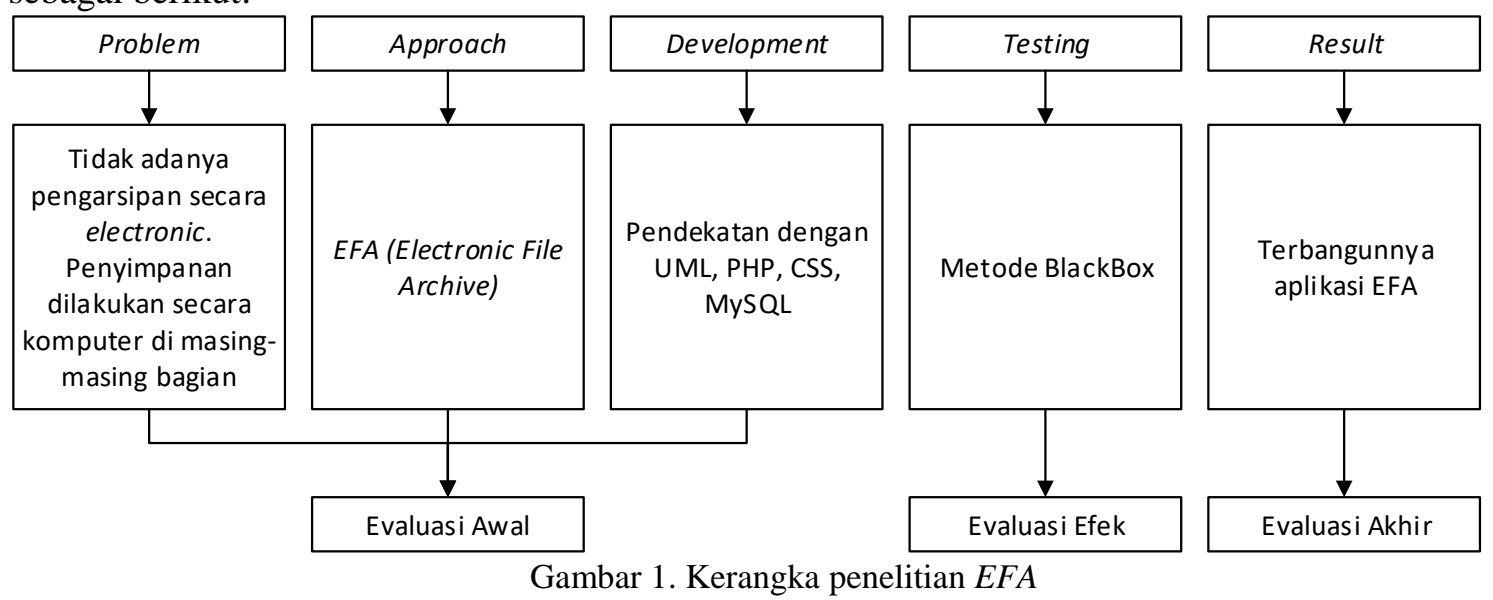

\subsection{Analisis Sistem yang Berjalan}

Sistem yang berjalan pada PLTA yaitu setiap bagian pada perusahan tersebut melakukan pengarsipan tersimpan di komputer masing-masing bagian. Adanya pembagian data kurang efektif antar bagian berdasarkan wawancara dengan pihak perusahaan, walaupun telah terkoneksi jaringan $L A N$. Kedua adanya hilang data atau rentan terinfeksi virus komputer karena sistem operasi yang digunakan yaitu windows. Terakhir, komunikasi antar pegawai untuk komunikasi transaksi pembagian data memerlukan foto yang diunggah untuk konfirmasi melalui whastapp atau dengan tools sejenis. Ilustrasi dapat dilihat pada Gambar 2.

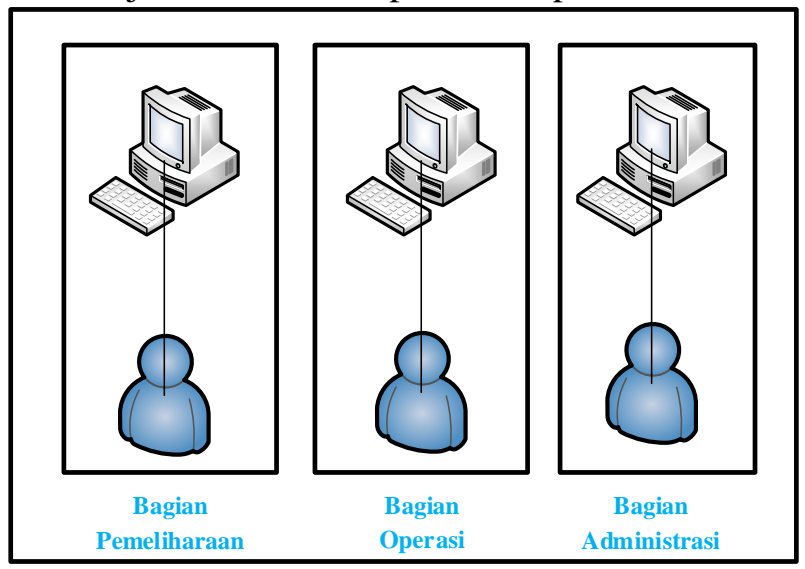

Gambar 2. Analisis sistem yang berjalan

\subsection{Analisis Sistem yang Diusulkan}

Sistem yang diusulkan dapat dilihat pada ilustrasi Gambar 3. EFA diimplementasikan pada server yang terhubung dengan jaringan lokal PLTA. Setiap bagian dapat melakukan upoload dan download pada aplikasi EFA. Komunikasi antar bagian dapat dilakukan dengan aplikasi EFA. 


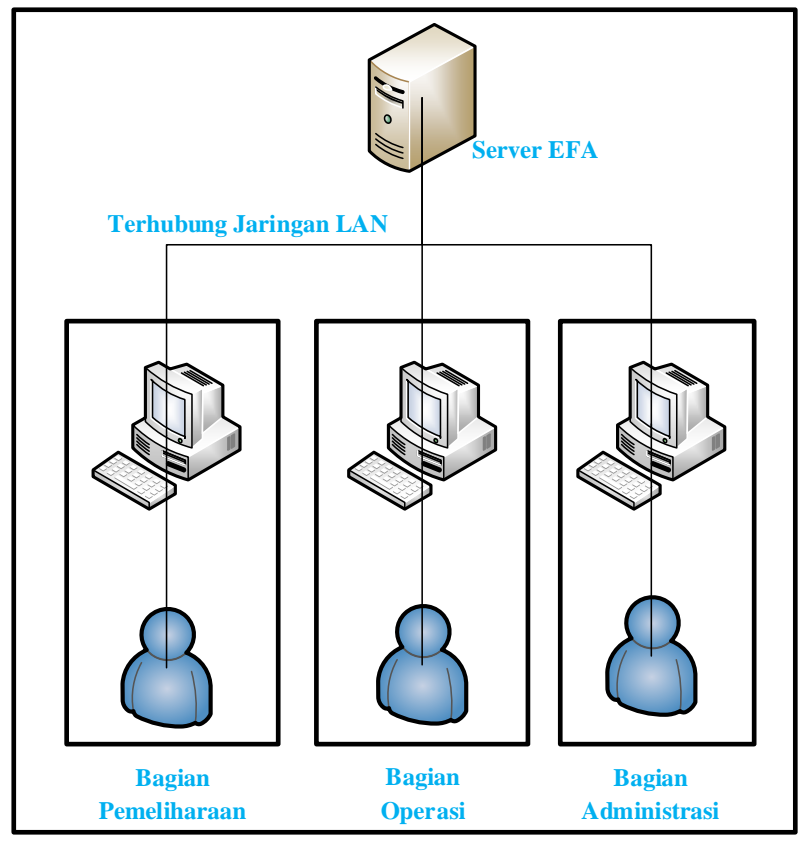

Gambar 3. Analisis sistem yang diusulkan

\section{PEMBAHASAN}

\subsection{Perancangan Sistem}

\subsubsection{Entity Relationship Diagram (ERD)}

Rancangan ERD dan PDM EFA terlihat pada gambar 4. EFA memiliki tabel tb_pengguna, tb_level, tb_kategori, tb_file, history_file, tb_forum dan history_forum.

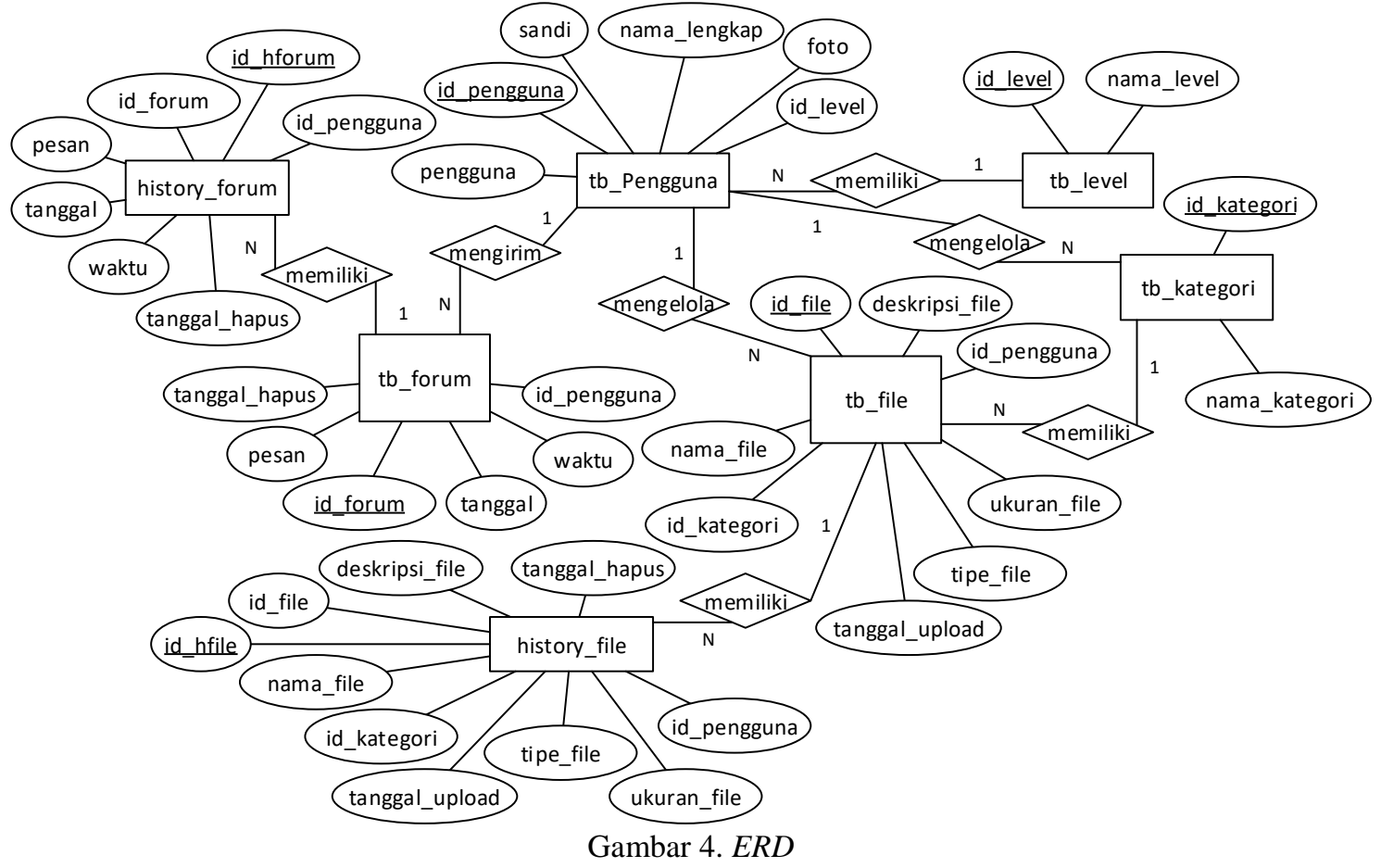




\subsubsection{Use Case Diagram}

Use Case Diagram memaparkan bagaimana aliran masukan dan keluaran dari sistem yang dibangun, dapat dilihat pada Gambar 5.

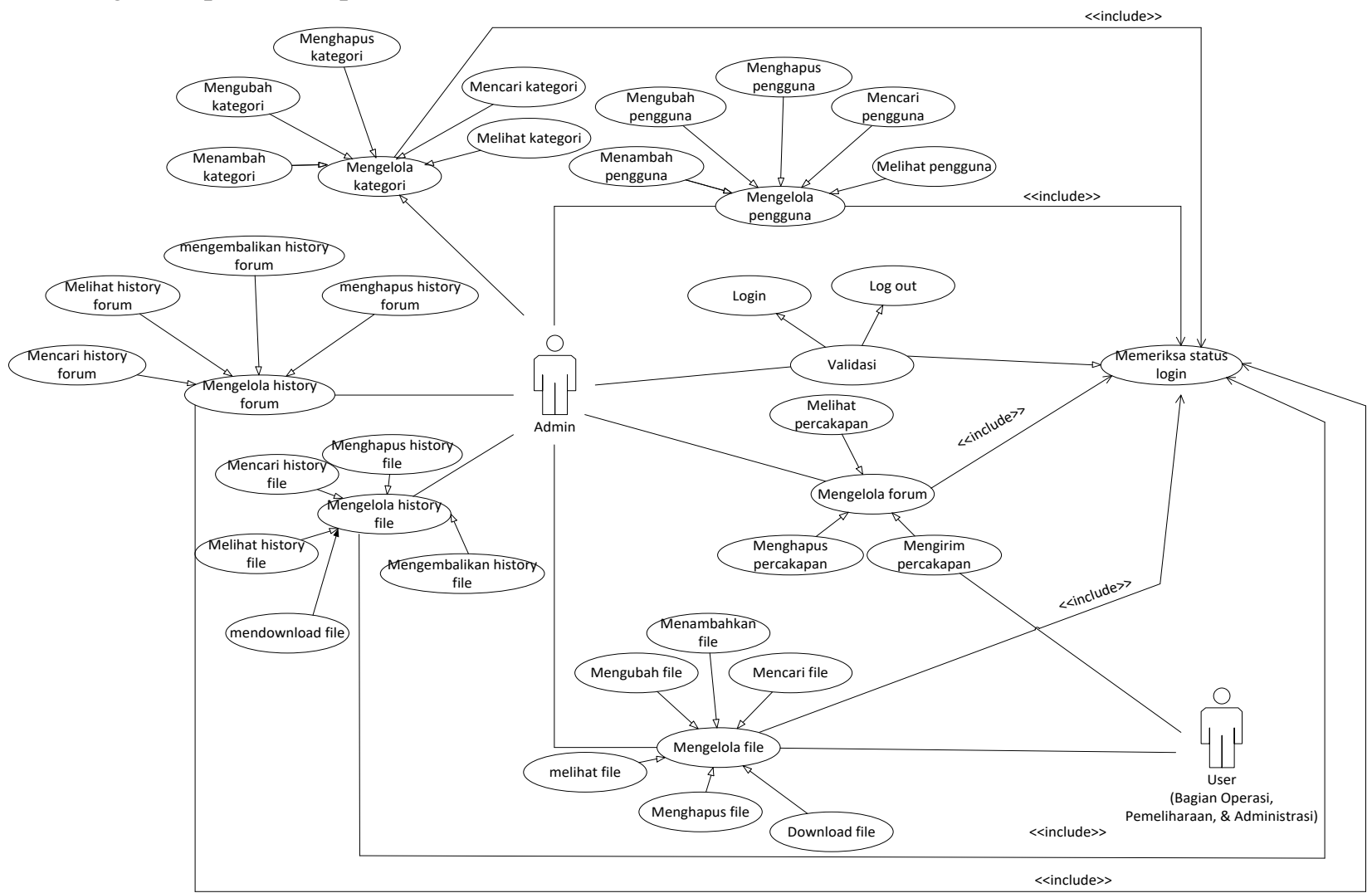

Gambar 5. Use Case Diagram

\subsection{Implementasi Rancangan $\boldsymbol{E F A}$}

Hasil implementasi rancangan EFA memiliki dua level yaitu admin dan user. Admin mengatur seluruh pada aplikasi $E F A$ dan user sebagai pengguna masing-masing bagian pada PLTA.

\subsubsection{Halaman Utama}

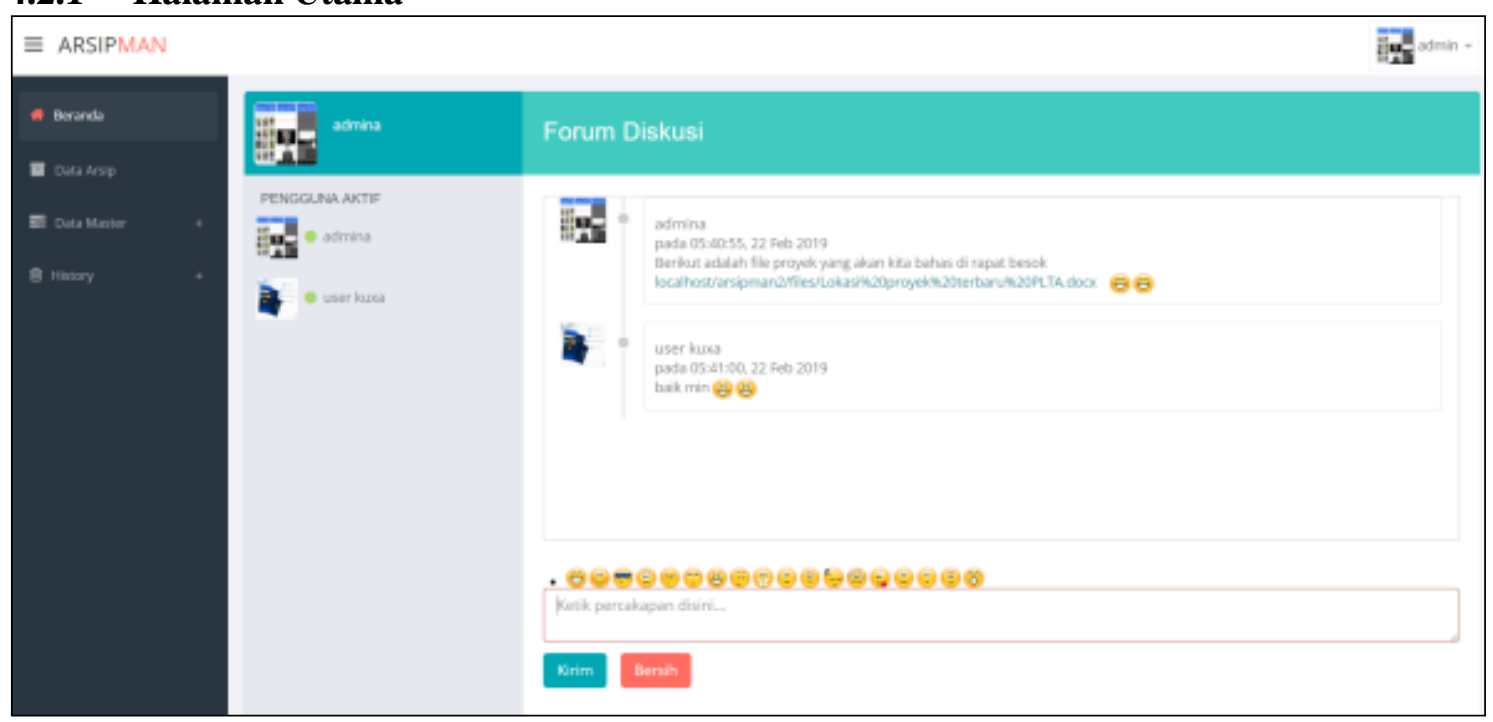

Gambar 6. Halaman utama admin 
Gambar 6 merupakan implementasi halaman utama admin. Halaman admin memiliki menu diantaranya adalah data arsip, data master (Master pengguna dan kategori), history (History file dan percakapan). Halaman utama ini juga memiliki forum yang berguna untuk saling mengirim percakapan. Fungsi utama forum ini yaitu untuk pemberitahuan baik file baru, kegiatan, maupun hal-hal yang berkaitan dengan pengarsipan file.

\subsubsection{Halaman Data Arsip admin}

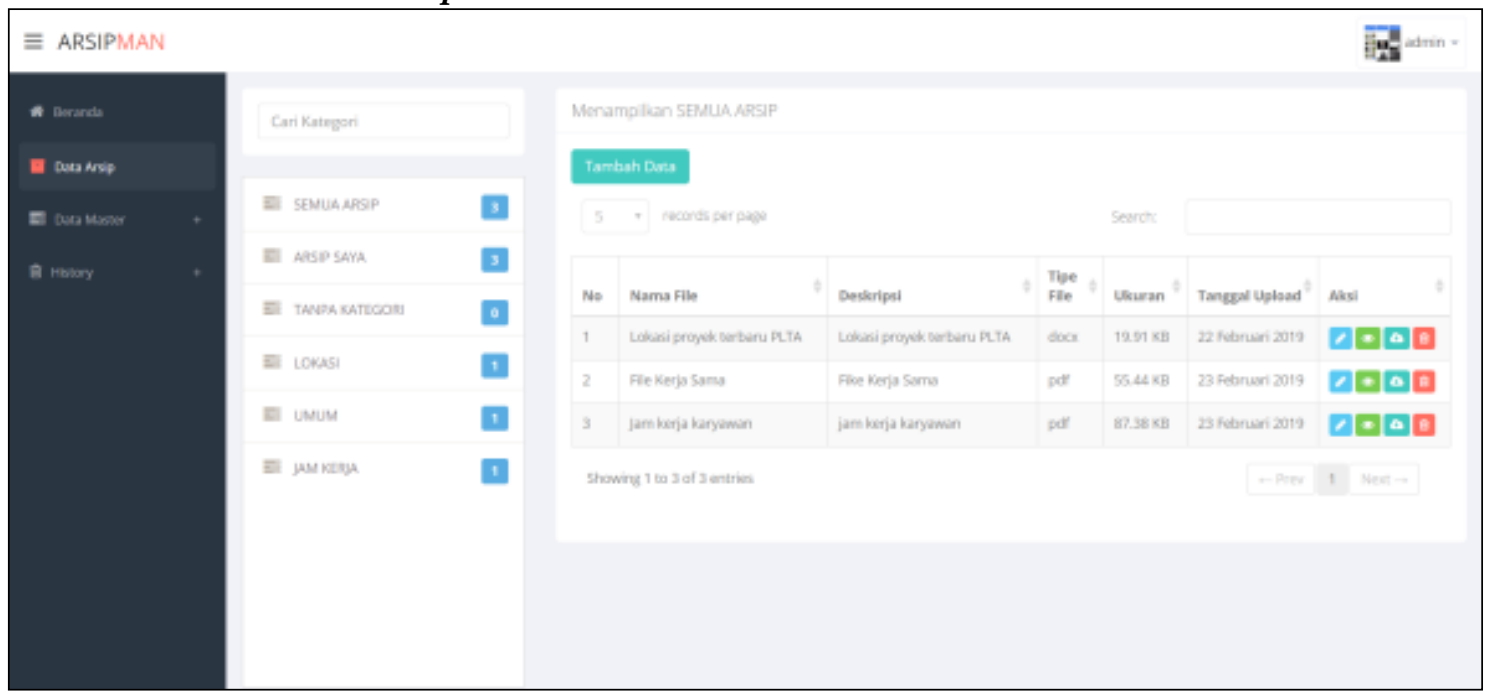

Gambar 7. Halaman data arsip admin

Gambar 7 merupakan implementasi jalaman data arsip. Halaman data arsip memuat fitur untuk melihat semua data arsip, arsip saya, arsip dengan kategori, dan arsip tanpa kategori. Pada halaman ini juga bisa menambahkan file, mengubah, view, download dan hapus.

\subsubsection{Halaman Upload File admin}

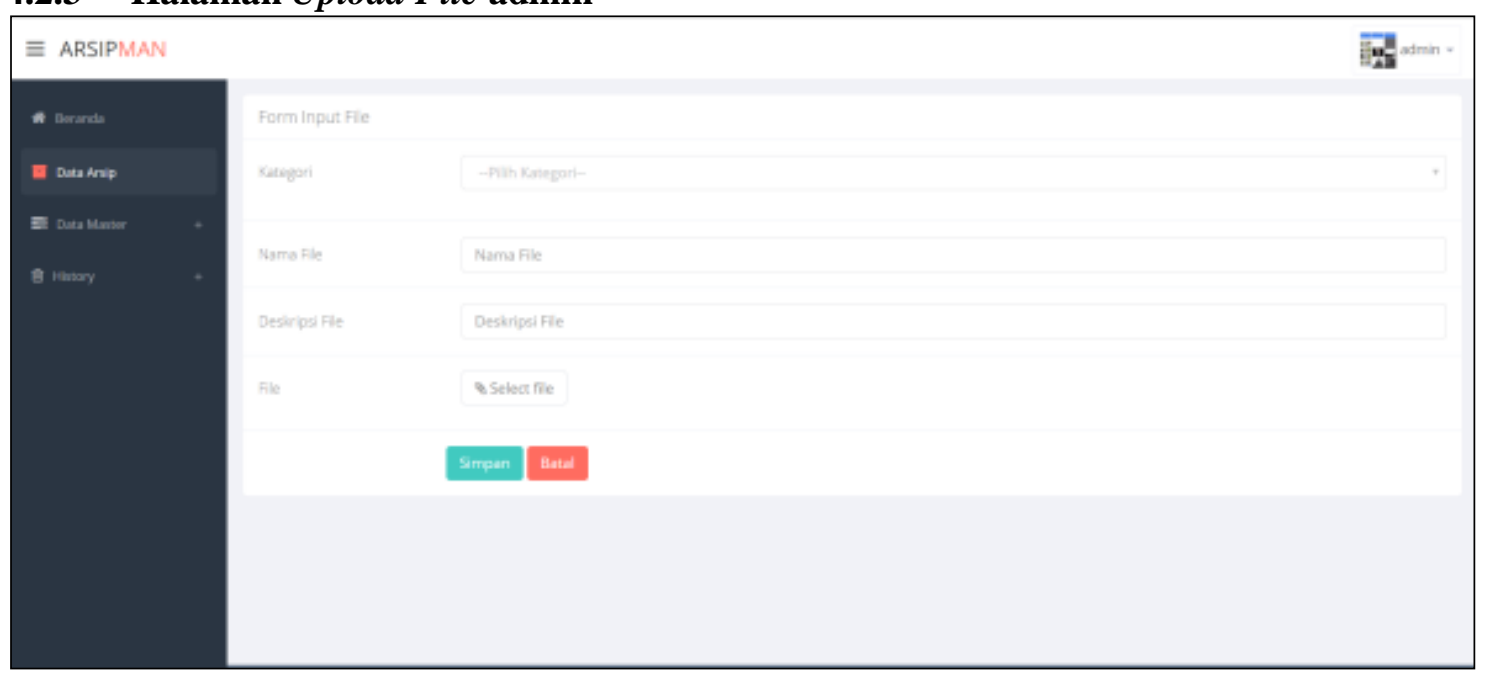

Gambar 8. Halaman upload file admin

Gambar 8 merupakan implementasi halaman upload file pada admin. Beberapa atribut yang dimasukkan adalah kategori file, nama, deskripsi, dan file. 


\subsubsection{Halaman History Percakapan admin}

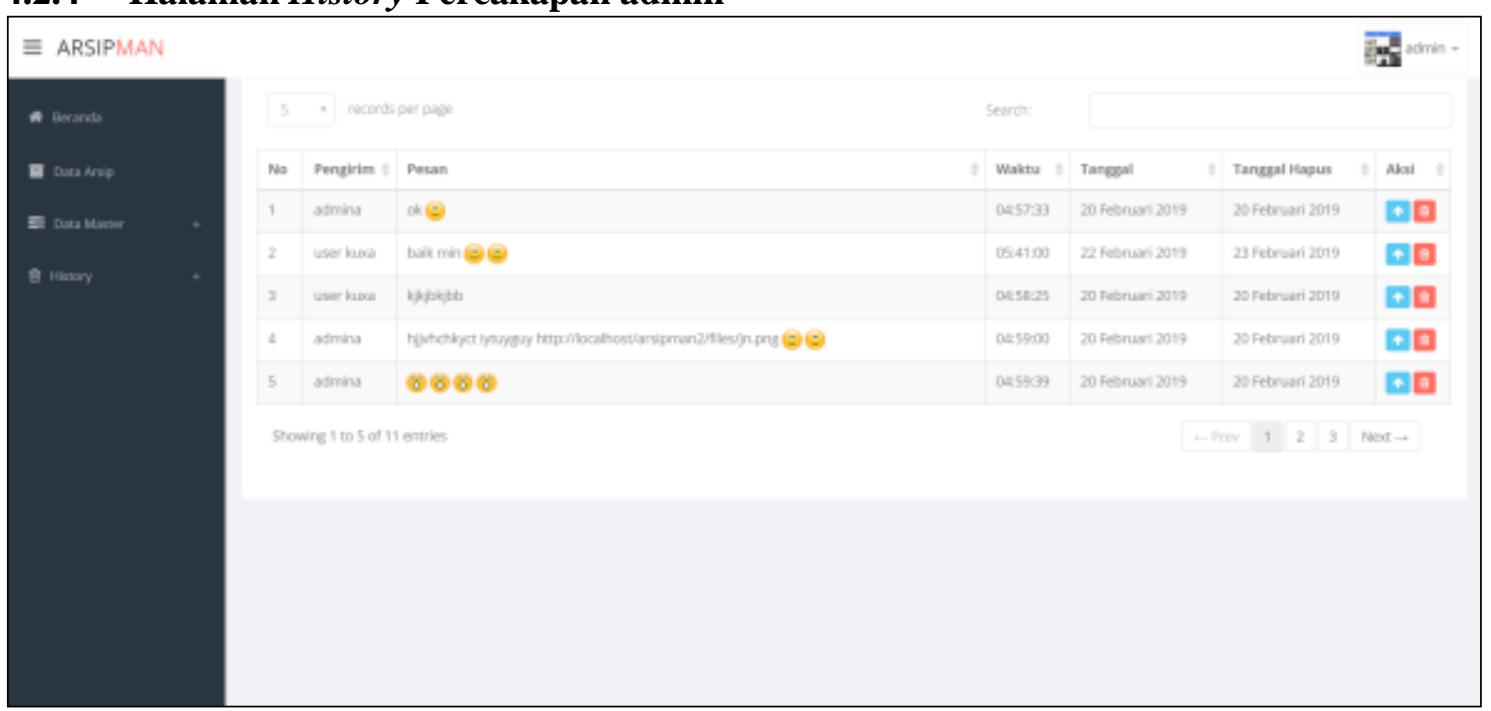

Gambar 9. Halaman history percakapan

Gambar 9 merupakan implementasi halaman history perckapan. Halaman ini memuat semua percakapan yang telah dihaus oleh admin. Data percakapan bisa dihapus permanen atau dikembalikan kedalam forum perckapan.

\subsubsection{Halaman History Arsip admin}

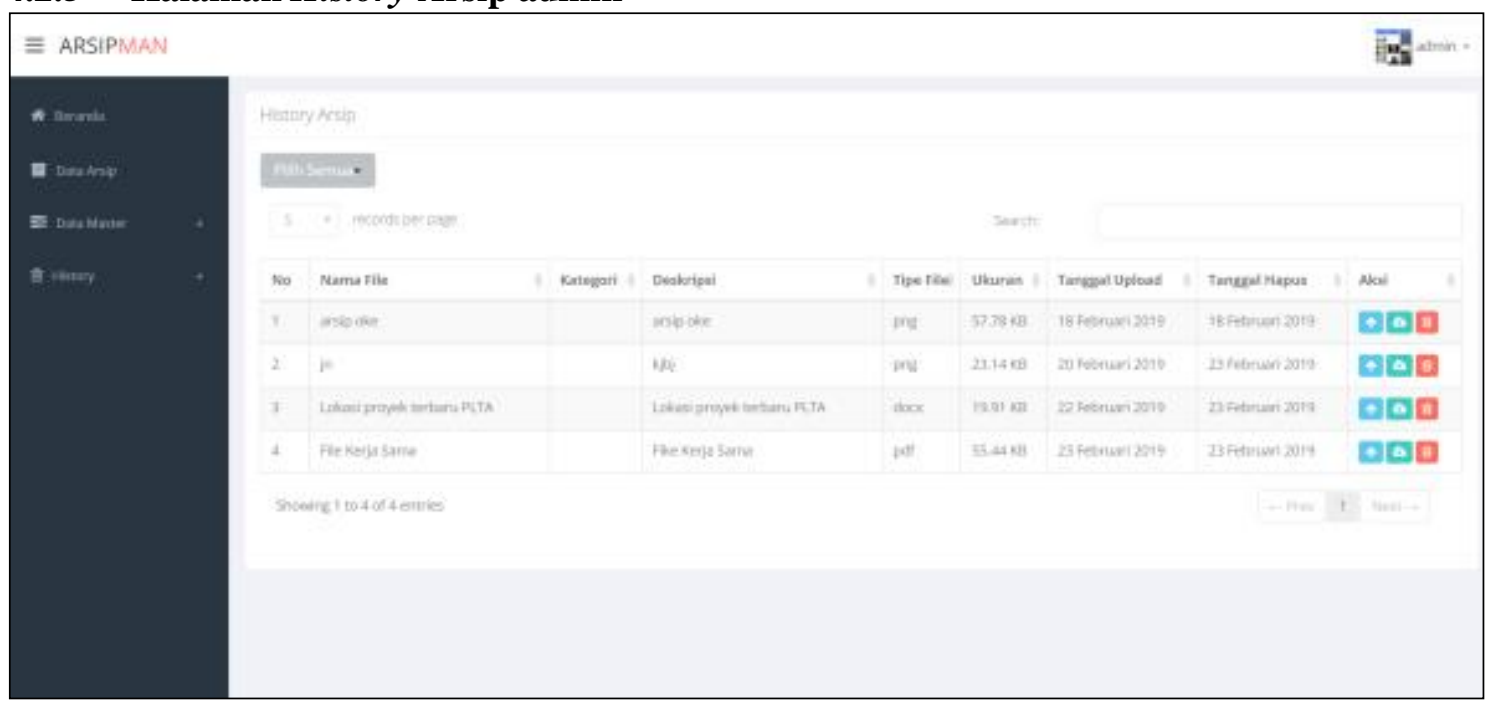

Gambar 10. Halaman history arsip

Gambar 10 merupakan implementasi halaman history arsip. Halaman ini memuat data arsip yang telah di hapus. File yang ada di halaman ini bisa dihapus permanen atau dikembalikan ke data arsip. 


\subsubsection{Halaman Utama User}

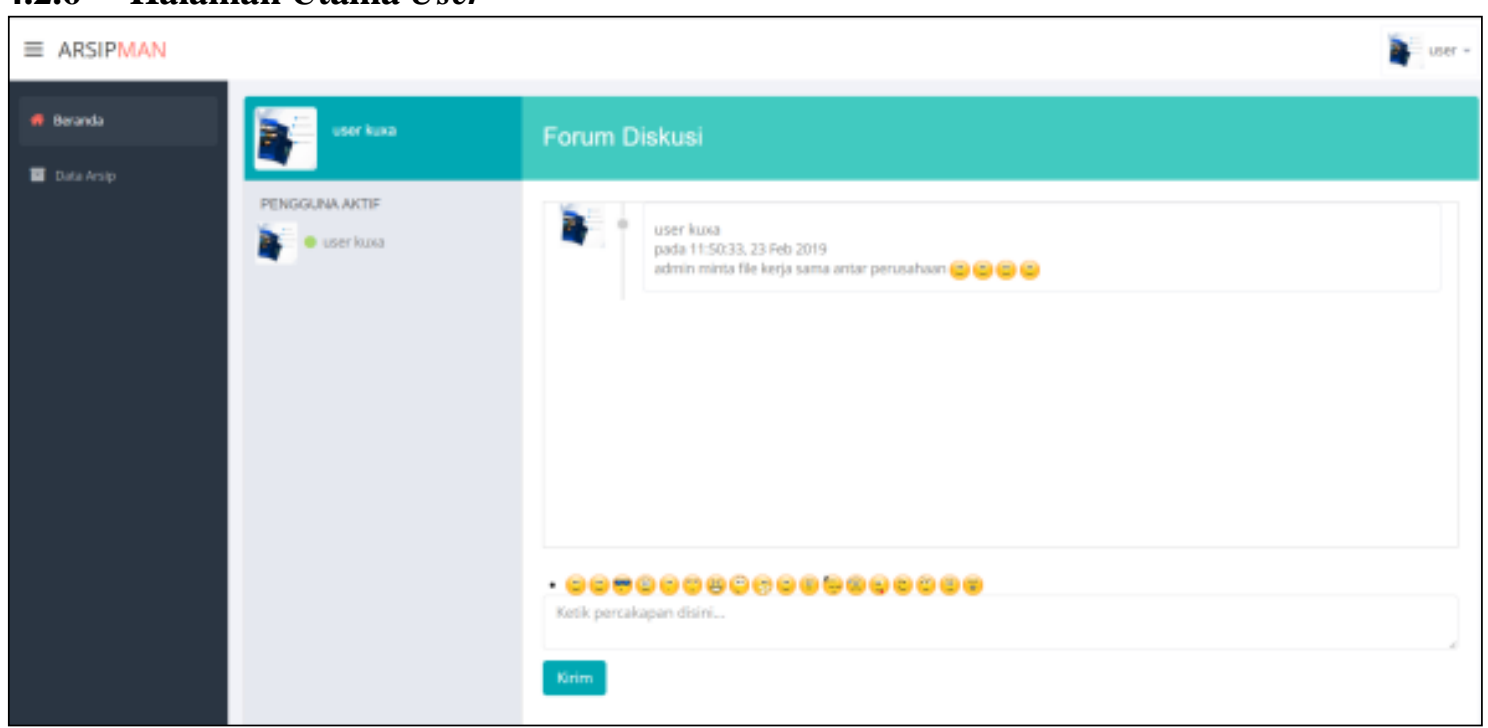

Gambar 11. Halaman utama user

Gambar 11 merupakan implementasi halaman utama untuk user. Halaman ini user bisa mengirimkan percakapan di forum. Selain itu user juga bisa melihat dan mengarsipkan file di meni data arsip.

\subsubsection{Halaman Data Arsip User}

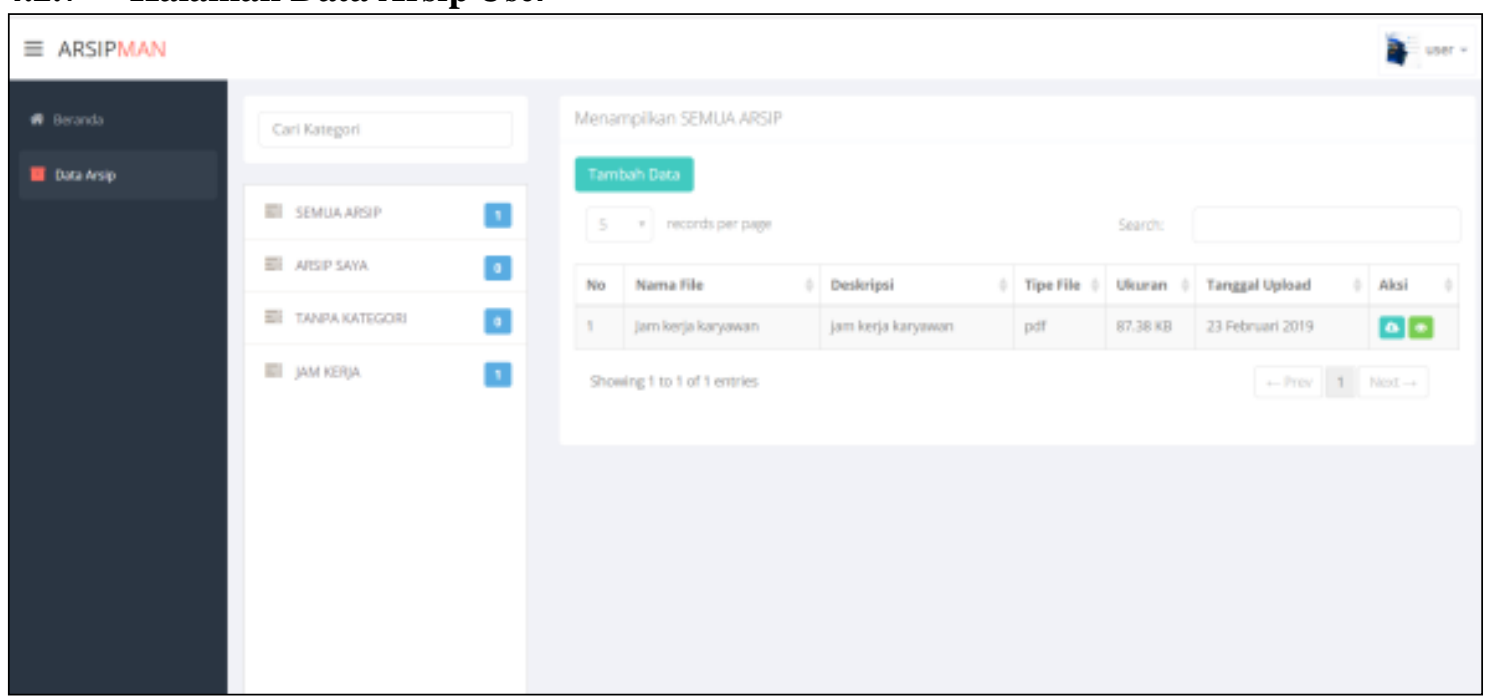

Gambar 12. Halaman data arsip user

Gambar 12 merupakan implementasi halaman data arsip untuk user. Halaman ini memuat data arsip yang memiliki kategori semua arsip, arsip saya, tanpa kategori, dan kategori. Pada halaman ini juga user dapat menambahkan file, melihat, mendownload dan mengedit file khusus yang telah diupload oleh user.

\subsection{Implementasi EFA pada Server PLTA}

Implementasi EFA telah install pada server lokal dengan alamat 20.20.22.206/arsipman. Server yang digunakan menggunakan OS Linux ubuntu 16.04 LTS 64 Bit 


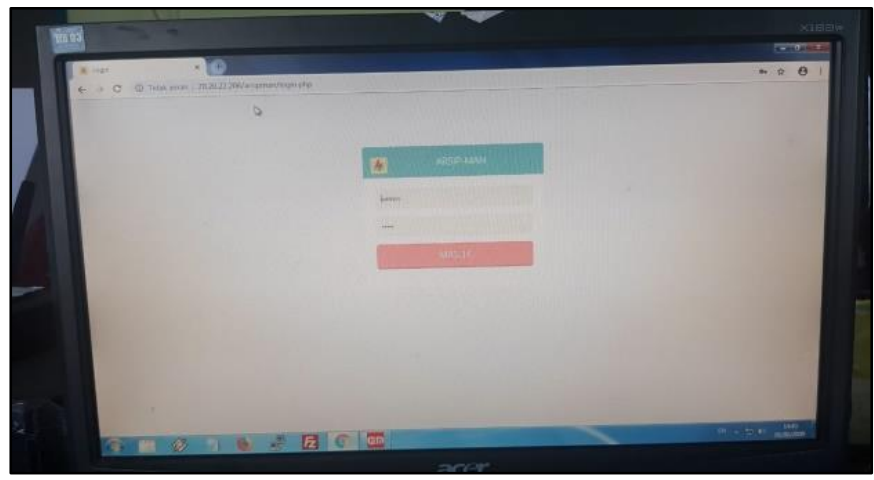

Gambar 13. Implementasi EFA di server

\subsection{Pengujian Black box}

Pengujian blackbox berfokus pada persyaratan fungsional perangkat lunak. Pengujian ini memungkinkan analis sistem memperoleh kumpulan kondisi input yang akan mengerjakan seluruh keperluan fungsional program. Pengujian blackbox EFA dilakukan seluruh halaman pada level admin maupun level user. Seluruh form setiap menu EFA dilakukan pengujian blackbox dinyatakan berhasil. Gambar 14 merupakan salah satu penerapan pengujian blackbox EFA.

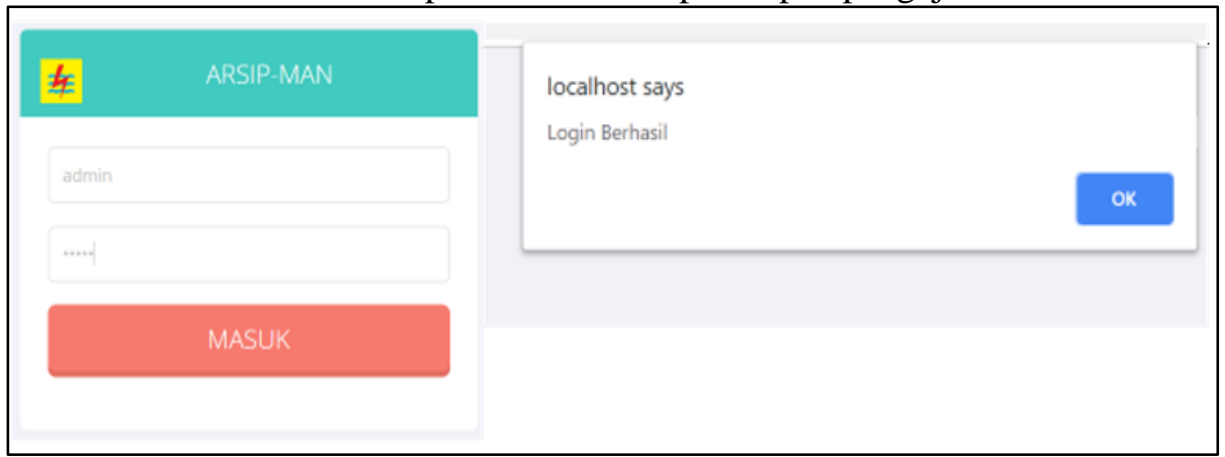

Gambar 14. Pengujian BlackBox halaman login

Tabel 1 pengujian sistem form login merupakan hasil pengujian black box yang telah ditetapkan.

Tabel 1. Pengujian sistem form login

\begin{tabular}{|c|c|c|c|}
\hline Data Masukan & Yang Diharapkan & Pengamatan & Kesimpulan \\
\hline \multicolumn{4}{|c|}{ Kasus Dan Hasil Uji (Data Normal) } \\
\hline $\begin{array}{l}\text { Data login Admin } \\
\text { Username: Admin } \\
\text { Password: Admin }\end{array}$ & $\begin{array}{l}\text { Tercantum pada textbox } \\
\text { username dan password. }\end{array}$ & $\begin{array}{l}\text { Dapat mengisi textbox } \\
\text { Username dan password berupa } \\
\text { bintang. }\end{array}$ & $\begin{array}{l}\text { * }] \text { diterima } \\
{[\quad] \text { ditolak }}\end{array}$ \\
\hline Klik Tombol Login & $\begin{array}{l}\text { Dapat masuk ke form } \\
\text { selanjutnya }\end{array}$ & $\begin{array}{l}\text { Tombol login dapat berfungsi } \\
\text { sesuai yang diharapkan. }\end{array}$ & $\begin{array}{l}{[* \text { ] diterima }} \\
{[\quad] \text { ditolak }}\end{array}$ \\
\hline \multicolumn{4}{|c|}{ Kasus Dan Hasil Uji(Data Salah) } \\
\hline $\begin{array}{l}\text { Data login Admin } \\
\text { Username: kosong } \\
\text { Password: kosong }\end{array}$ & $\begin{array}{l}\text { Tidak Tercantum pada } \\
\text { textbox Username dan } \\
\text { password }\end{array}$ & $\begin{array}{l}\text { tidak mengisi textbox berupa } \\
\text { bintang. }\end{array}$ & $\begin{array}{l}{[* \text { ] diterima }} \\
{[\quad] \text { ditolak }}\end{array}$ \\
\hline \multicolumn{4}{|c|}{ Kasus Dan Hasil Uji(Data Salah) } \\
\hline Klik Tombol Login & Tidak Dapat Login & $\begin{array}{l}\text { Tombol login tidak dapat } \\
\text { berfungsi sesuai yang } \\
\text { diharapkan. }\end{array}$ & 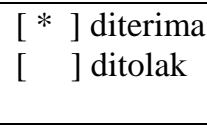 \\
\hline $\begin{array}{l}\text { Data login Admin } \\
\text { Username: Admin } \\
\text { Password: kosong }\end{array}$ & $\begin{array}{l}\text { Tercantum pada textbox } \\
\text { Username dan password } \\
\text { kosong. }\end{array}$ & $\begin{array}{l}\text { Dapat mengisi textbox } \\
\text { Username dan password } \\
\text { kosong. }\end{array}$ & $\begin{array}{l}{[* \text { ] }} \\
{\left[\begin{array}{l}* \\
{[}\end{array}\right] \text { diterima }} \\
\end{array}$ \\
\hline Klik Tombol Login & Tidak Dapat Login & $\begin{array}{l}\text { Tombol login tidak dapat } \\
\text { berfungsi sesuai yang } \\
\text { diharapkan. }\end{array}$ & $\begin{array}{l}{[* \text { ] }} \\
{\left[\begin{array}{l}* \\
{[}\end{array}\right] \text { diterima }} \\
\end{array}$ \\
\hline
\end{tabular}




\begin{tabular}{|c|c|c|c|}
\hline Data Masukan & Yang Diharapkan & Pengamatan & Kesimpulan \\
\hline $\begin{array}{l}\text { Data login Admin sql } \\
\text { injection } \\
\text { Username: 'OR 'I'='I } \\
\text { Password: 'OR 'I'='I }\end{array}$ & $\begin{array}{l}\text { Tercantum pada textbox } \\
\text { Username dan password. }\end{array}$ & $\begin{array}{l}\text { Dapat mengisi textbox } \\
\text { Username dan password berupa } \\
\text { bintang. }\end{array}$ & $\begin{array}{l}{[* \text { ] diterima }} \\
{[\quad] \text { ditolak }}\end{array}$ \\
\hline Klik Tombol Login & Tidak Dapat Login & $\begin{array}{l}\text { Tombol login tidak dapat } \\
\text { berfungsi sesuai yang } \\
\text { diharapkan. }\end{array}$ & $\begin{array}{l}{[* \text { ] diterima }} \\
{[\text { ] ditolak }}\end{array}$ \\
\hline
\end{tabular}

\section{KESIMPULAN}

Kesimpulan yang diambil dari pembuatan $E F A$ yaitu:

a. Telah dibangun EFA sederhana berbasis web, sehingga dapat membantu Perusahaan PT. PLN (Persero) Unit Induk Pembangkitan dan Penyaluran Kalimantan UPDK Barito ULPLTA Ir. P.M. Noor.

b. Pengujian sistem EFA sederhana berbasis web pada PT. PLN (Persero) Unit Induk Pembangkitan dan Penyaluran Kalimantan UPDK Barito ULPLTA Ir. P.M. Noor menggunakan pengujian sistem Black Box berjalan dengan baik secara fungsional.

\section{DAFTAR PUSTAKA}

Asmara, B. P. (2014). Digitalisasi Arsip Dokumen Penting Sebagai File Lokal Interest (LI) Dengan Soft Komputing Sebagai Daya Dukung Informasi Berbasis ICT. ELECTRICHSAN, 1(2), 8-20.

Kuswantoro, A. (2015). Model Elektronik Arsip (E Arsip) Pembelajaran Berbasis Virtual dan Microsoft Access Pada SMK Program Keahlian Administrasi Perkantoran. EFISIENSIKajian Ilmu Administrasi, 13(2), 98-110.

Pratiwi, H. (2014). Sistem Pendukung keputusan Penentuan Karyawan Berprestasi Menggunakan Metode Multifactor Evaluation Process. Jurnal Sistem Komputer, 5(2), 95-101.

Rosa, A. S., \& Shalahuddin, M. (2013). Rekayasa Perangkat Lunak Terstruktur dan Berorientasi Objek. Bandung: Informatika.

Setiawan, W. (2017). Era Digital dan Tantangannya. In Seminar Nasional Pendidikan 2017 (pp. 1-9). Sidik, A., Sakuroh, L., \& Pratiwi, D. (2017). Perancangan Sistem Infomasi Filling di PT BCA Cabang MH Thamrin Tangerang. Jurnal Sisfotek Global, 7(2), 81-86.

\section{Biodata Penulis}

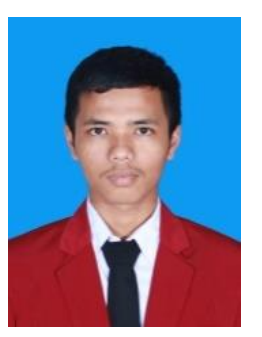

Suharmadi, lahir di Tanah Laut pada tanggal 19 Agustus 1997. Penulis kedua menyelesaikan Sekolah Menengah Atas di SMAN 1 Jorong pada tahun 2016 dan melanjutkan pendidikan ke Politeknik Negeri Tanah Laut. Saat ini penulis pertama telah menempuh semester VI di Jurusan Teknik Informatika Politeknik Negeri Tanah Laut dan sedang menyelesaikan Tugas Akhir untuk memperoleh gelar A.Md.

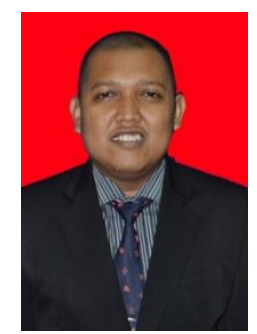

Hendrik Setyo Utomo, meraih gelar Sarjana Teknik (S.T) Jurusan Teknik Informatika dari Universitas Gunadarma dan menyelesaikan Magister Manajemen Sistem informasi (M.M.S.I) pada Program Studi Manajemen Sistem Informasi dari Universitas Gunadarma. Menjadi dosen Program Studi teknik Informatika di Politeknik Negeri Tanah Laut sejak 2012 sampai saat ini (2019). E-mail: hendrik.tomo@politala.ac.id dan nomor telepon: 081511180492. 